\title{
Potensi Pencairan Batubara Kalimantan Timur Sebagai Bahan Bakar Cair Berdasarkan Kajian Geokimia Organik Degradasi Fraksi Polar Batubara, Pit Kancil, Kalimantan Timur
}

\author{
Bellina Yunitasari \\ Jurusan Teknik Mesin Universitas Negeri Surabaya \\ bellinayunitasari@unesa.ac.id
}

\begin{abstract}
ABSTRAK
Karakteristik biomarka hidrokarbon batubara Pit Kancil, Sangatta, Kalimantan Timur dapat memberikan informasi mengenai sumber bahan organik, lingkungan pengendapan, proses diagenesis dan kematangan batubara. Sampel batubara diekstraksi dengan metode soklet untuk memisahkan senyawa biomarka dari matrik sampel. Ekstrak biomarka difraksinasi menggunakan metode kromatografi kolom, sehingga diperoleh fraksi polar untuk selanjutnya di degradasi dan diidentifikasi menggunakan kromatografi gas-spektrometri massa (KG-SM). Analisa geokimia organik hidrokarbon hasil degradasi fraksi polar batubara pit Kancil, Sangatta, Kalimantan Timur diperoleh biomarka diantaranya n-alkana $\mathrm{C}_{11}-\mathrm{C}_{23}$, alkil naftalena dan biomarka alkil fenantrena. Hasil analisa biomarka menunjukkan bahwa masukan organik batubara berasal dari tumbuhan tingkat tinggi sub-devisi Gimnospermae pada zaman Miosen dan telah melewati proses diagenesis dengan tingkat kematangan batubara yang rendah. Berdasarkan analisa biomarka, dan korelasi terhadap produk pencairan batubara, maka batubara Pit Kancil, Sangatta, Kalimantan Timur berpotensi untuk dicairkan pada proses pemanfaatannya sebagai bahan bakar kerosine dan solar.
\end{abstract}

Kata Kunci: Batubara, Biomarka, Kalimantan, Sangatta, Polar

\begin{abstract}
Characteristics of coal hydrocarbon biomarkers Kancil Pit, Sangatta, East Kalimantan can provide information on sources of organic matter, depositional environment, diagenesis processes and coal maturity. Coal samples were extracted using the soclet method to separate biomarkers from the sample matrix. The biomarka extract was fractionated using column chromatography method, so that the polar fraction was obtained to be subsequently degraded and identified using gas chromatography-mass spectrometry (GC-MS). Organic hydrocarbon geochemical analysis results of degradation of Kancil pit polar coal fraction, Sangatta, East Kalimantan obtained biomarkings including n-alkane C11-C23, alkyl naphthalene and alkyl phenanthrene biomarkers. The results of biomarker analysis showed that the organic input of coal was derived from highlevel plants sub-division of Gimnosperms in the Miocene era and had undergone a process of diagenesis with a low maturity level of coal. Based on the biomarker analysis, and the correlation with coal liquefaction products, the Kancil Pit coal, Sangatta, East Kalimantan has the potential to be disbursed in the utilization process as kerosine and diesel fuel.
\end{abstract}

Keywords: Coal, Biomarka, Kalimantan, Sangatta, Polar 


\section{PENDAHULUAN}

Ketersediaan batubara sebagai salah satu sumber energi di Indonesia sangat melimpah yaitu sebesar 104,8 miliar ton, dengan cadangan sebesar 20,98 miliar ton (Girianna, 2012).Batubara menjadi salah satu alternatif bahan bakar yang digunakan setelah minyak dan gas bumi, karena harganya relatif murah. Cadangan batubara di Indonesia cukup banyak, yaitu empat kali lebih banyak dari cadangan minyak dan gas bumi. Kalimantan termasuk salah satu penghasil batubara yang potensial, yakni $51 \%$ cadangan batubara Indonesia ada di Kalimantan (Nugroho, 2006).

Tipe dari struktur hidrokarbon yang ditemukan pada bahan bakar fosil (batubara, minyak bumi) berhubungan dengan tahap-tahap degradasi dari bahan organik tersebut selama pemendaman yang sangat dipengaruhi oleh faktor lingkungan seperti temperatur, tekanan, kelembapan, dan aktivitas mikroba di dalam tanah (Petrov, dkk., 1985).

Pengetahuan karakter batubara dapat dilakukan melalui analisa biomarka yang terkandung (Sukandarrumidi, 1995). Biomarka atau disebut penanda biologi, merupakan senyawa-senyawa organik yang berasal dari makhluk hidup yang terdapat dalam batuan dan sedimen, dan cenderung tidak mengalami perubahan kerangka yang berarti dari senyawa induknya sehingga dapat bermanfaat dalam penentuan lingkungan dahulu kala (Hazai, dkk., 1988; Peters dan Moldowan, 1993).

Dalam rangka penganeka ragaman energi, batubara merupakan energi alternatif yang mempunyai nilai strategis dan potensial untuk menghasilkan bahan bakar cair yang dapat menggantikan bahan bakar minyak bumi, sehingga diharapkan krisis energi dalam negeri dapat teratasi. Batubara akan mempunyai nilai tambah, ekonomis, dan efisien apabila di konversi dalam bentuk minyak dan gas sintetik atau bahan petrokimia lain melalui proses likuifikasi dan atau gasifikasi. Proses pencairan batubara diperlukan karakteristik batubara, baik sifat fisik maupun sifat kimia, sehingga perlu adanya metode pencairan dengan memperhitungkan komposisi kimia minyak (Karlsson, 1990). Tahapan pertama proses konversi dari batubara padat menjadi cair diperlukan karakteristik dari batubara sampel (Legarreta, dkk, 1987). Salah satu data kimia yang berperan sebelum melakukan pencairan batubara adalah data geokimia organik. Berdasarkan data geokimia organik, dapat diketahui karakter kandungan biomarkanya, sehingga dapat memberikan gambaran tentang kemungkinan potensi pencairan batubara menjadi bahan bakar cair.

Perencanaan pencairan tersebut membutuhkan karakteristik khas batubara dan kandungan biomarka khas tersebut belum pernah diungkapkan dan perlu diungkapkan.

Pada penelitian ini akan dibahas karakteristik batubara Pit Kancil, Sangatta, Kalimantan Timur berdasarkan kandungan biomarka fraksi polar. Profil kandungan ini akan memberikan informasi mengenai sumber bahan organik, lingkungan pengendapan, proses diagenesis dan kematangan batubara. Perolehan informasi berdasarkan hasil analisa biomarka tersebut diharapkan dapat digunakan sebagai tolak ukur pengetahuan tentang potensi penggunaan batubara.

\section{METODE PENELITIAN}

Metode penelitian dilakukan melalui tiga tahap, diantaranya (1) ekstraksi batubara, (2) Fraksinasi Bitumen, (3) Degradasi fraksi polar dan (4) Analisa KG-MS

\section{Ekstraksi Batubara}

\section{TINJAUAN PUSTAKA}

100 gram sampel batubara berukuran 100 mesh diekstraksi dengan $800 \mathrm{~mL}$ kloroform selama 72 jam. Ekstrak yang diperoleh dilarutkan dalam nheksana dan didiamkan selama 24 jam, sehingga seluruh aspalten mengendap. Selanjutnya bitumen yang diperoleh diuapkan dari pelarutnya (Tuo, 2003).

\section{Fraksinasi Bitumen}

Ekstrak bitumen yang diperoleh difraksinasi berdasarkan kepolarannya (dari nonpolar - polar) dengan kromatografi kolom silica gel dan dielusi berturut-turut menggunakan pelarut n-heksana, 
diklorometan, kemudian metanol. Fraksi-fraksi yang diperoleh dikeringkan dan ditimbang, dan didesulfurisasi dengan serbuk $\mathrm{Cu}$.

\section{Degradasi Fraksi Polar}

Fraksi polar sebanyak $20 \mathrm{~mL}$ dimasukkan tabung reaksi bertutup Teflon, ditambah asam iodida sebanyak $10 \mathrm{~mL}$, dikondisikan dibawah gas $\mathrm{N}_{2}$, dan dipanaskan pada suhu $110^{\circ} \mathrm{C}-120^{\circ} \mathrm{C}$ selama 6 jam pada tekanan normal. Hasil reaksi yang diperoleh, dimasukkan ke dalam corong pisah yang sudah diisi dengan aquabides, kemudian diekstrak dengan diklorometan. Ekstrak diklorometan (fasa organik) yang diperoleh, ditambah $\mathrm{N}_{2} \mathrm{SO}_{4}$ anhidrat, dievaporasi kemudian di fraksinasi dengan KLT dengan pembanding DBA (1,2,5,6 Dibenzantrasen) ditotolkan ditepi kiri dan kanan KLT. Selanjutnya plat dielusi dalam chamber dengan pelarut $n$-heksana. Fraksi yang memiliki harga $\operatorname{Rf} 0,6-1,0$ diambil lalu dilarutkan ke dalam $5 \mathrm{~mL}$ THF kering, kemudian ditambahkan reduktor LAH, direfluk selama 1 jam dengan mengalirkan gas $\mathrm{N}_{2}$ pada tekanan normal. Fraksi hasil reduksi selanjutnya disaring dengan corong tulip, dimasukkan dalam corong pisah yang telah berisi air dan diekstrak dengan dietil eter. Ekstrak dipekatkan menggunakan penguap vakum, kemudian dilarutkan dengan diklorometan dan dimasukkan dalam botol vial, dikeringkan dengan gas nitrogen, dan dianalisa dengan KG-SM.

\section{Analisa Senyawa dengan KG-MS}

Fraksi diidentifikasi menggunakan KG-SM dengan ionisasi (70 eV energi ionisasi) kolom kapiler silica Rtx-5 Ms (30 m x 0,32 mm, tebal film $0,25 \mu \mathrm{m})$. Temperatur injektor diatur pada suhu $250^{\circ} \mathrm{C}$ program suhu kolom diatur mulai $60^{\circ}$ $100^{\circ} \mathrm{C}$ dengan kenaikan $10^{\circ} \mathrm{C}$ per menit, selanjutnya $100^{\circ}-300^{\circ} \mathrm{C}$ dengan kenaikan $4^{\circ} \mathrm{C}$ per menit. Sebagai gas pembawa digunakan gas helium dengan kecepatan linier 2,3-8 mL permenit.

\section{HASIL DAN PEMBAHASAN}

Senyawa hidrokarbon hasil degradasi fraksi polar batubara pit Kancil, Sangatta, Kalimantan Timur dianalisa dengan KG-SM dan diperoleh kromatogram total seperti yang ditampilkan pada Gambar 1.

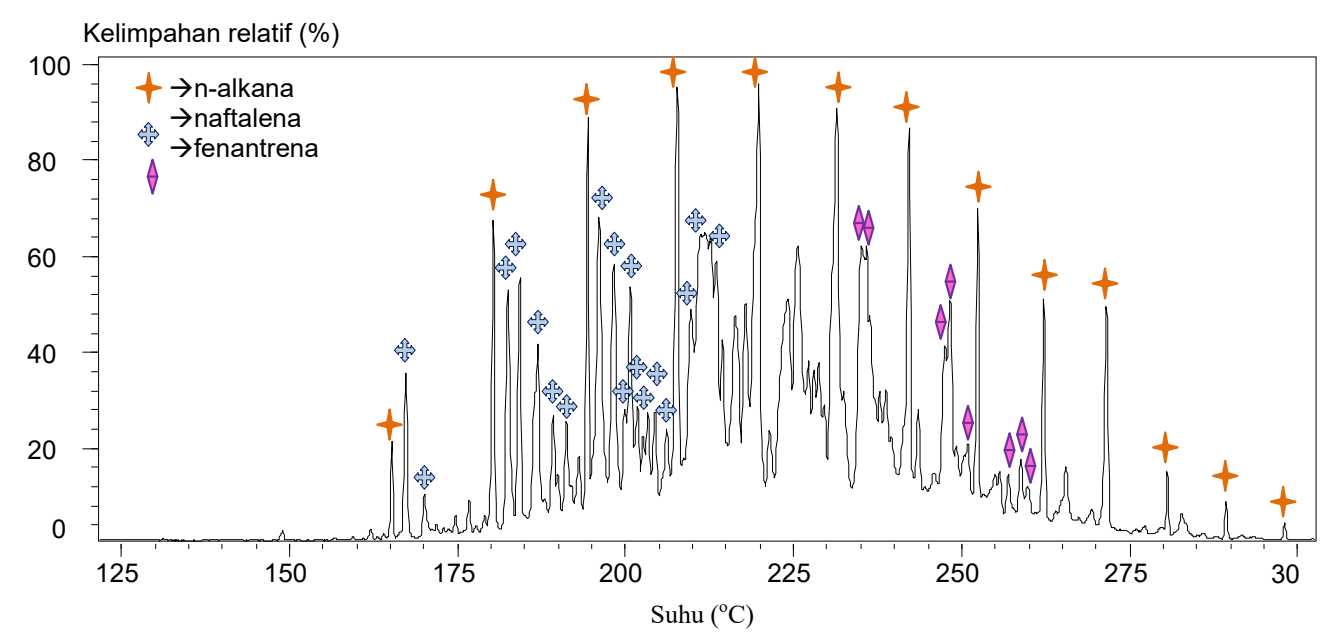

Gambar 1. Kromatogram Total Hidrokarbon Hasil Degradasi Fraksi Polar Batubara Pit Kancil, Sangatta Kalimantan Timur, Program Temperatur Oven $50^{\circ} \mathrm{C}\left(5\right.$ menit), $50^{\circ} \mathrm{C}-290^{\circ} \mathrm{C}\left(10^{\circ} \mathrm{C} / \mathrm{menit}\right)$, Isotermal $290^{\circ} \mathrm{C}$ selama 25 menit

Penelusuran terhadap kromatogram total tersebut ditemukan beberapa tipe biomarka antara lain n- alkana, alkil naftalena dan biomarka alkil fenantrena. 
Biomarka n-alkana diidentifikasi berdasarkan fragmentogram $\mathrm{m} / \mathrm{z} 57$, yang ditunjukkan pada

Biomarka n-Alkana

\section{Gambar 2.}

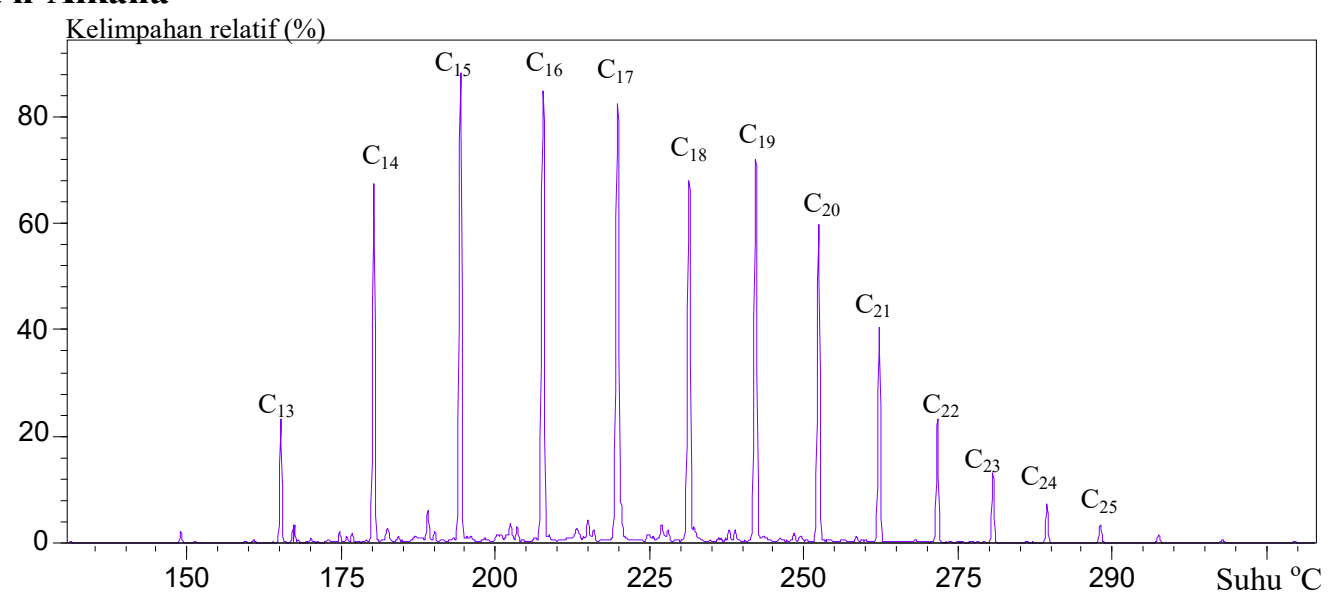

Gambar 2. Fragmentogram m/z 57 hidrokarbon hasil degradasi senyawa makromolekul batubara Pit Kancil, Sangatta, Kalimantan Timur, program temperatur oven $60 \mathrm{oC}-100 \mathrm{oC}, 10 \mathrm{oC} / \mathrm{menit}, 100 \mathrm{oC}-100 \mathrm{oC}$, $4 \mathrm{oC} /$ menit, isotermal $300 \mathrm{oC}$ selama 30 menit

Identifikasi lebih lanjut terhadap fragmentogram $\mathrm{m} / \mathrm{z} 57$ fraksi polar diperoleh spektrum massa

yang dua diantaranya ditampilkan pada Gambar 3 dan Gambar 4.

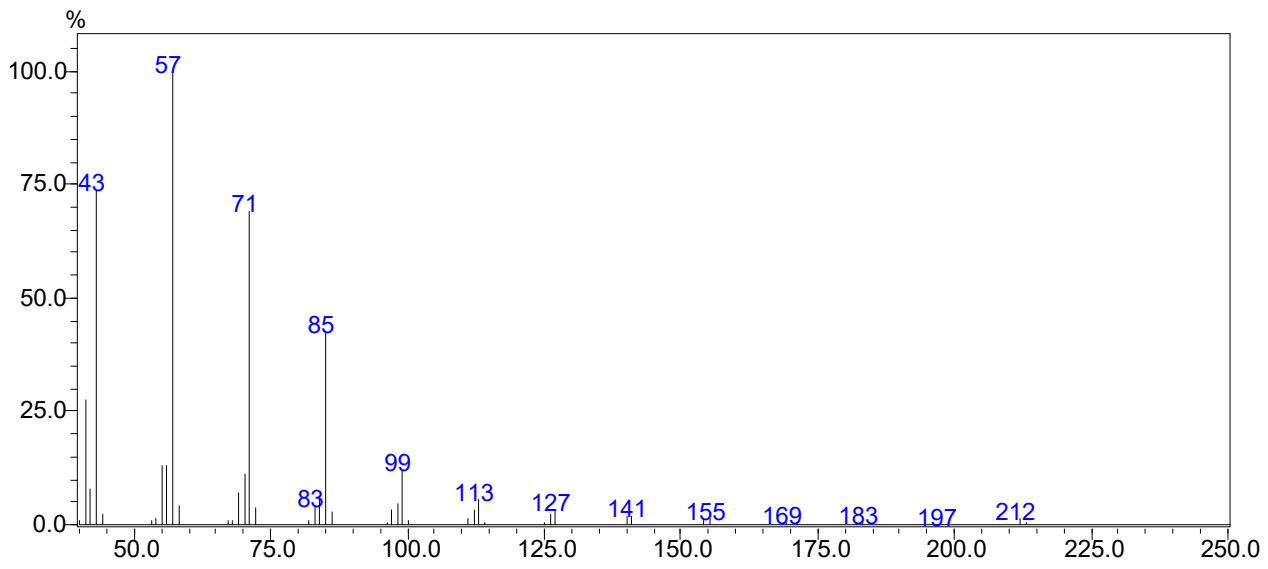

Gambar 3. Spektrum Massa C15 Fragmentogram m/z 57 Gambar 4.65 


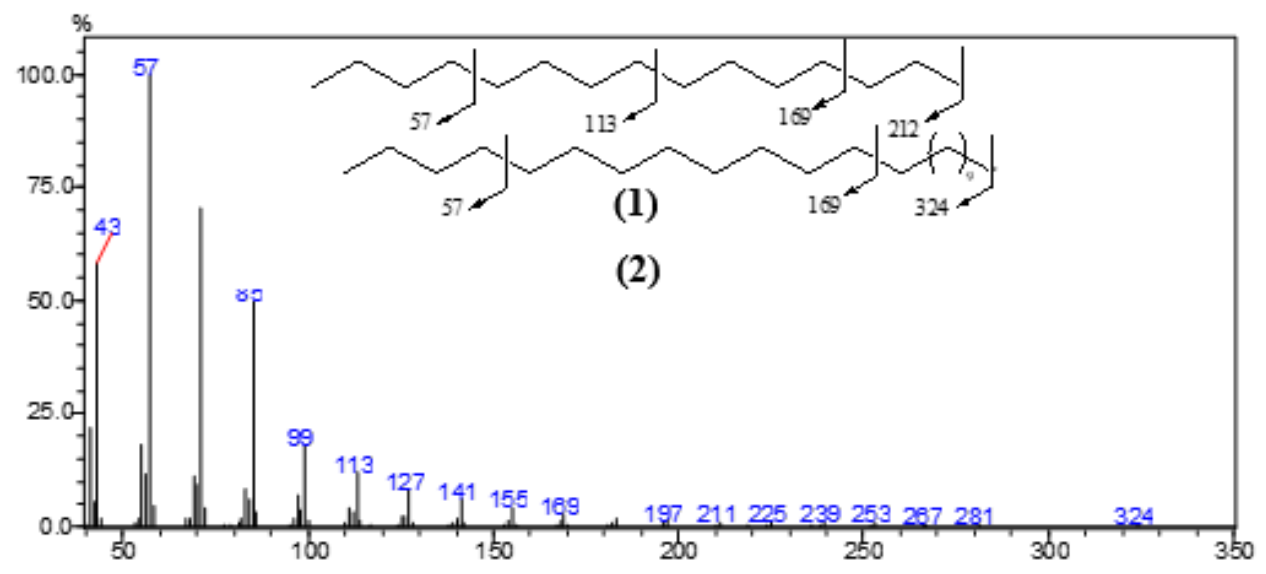

Gambar 4. Spektrum Massa C23 Fragmentogram m/z 57 Gambar 4.65

Elusidasi terhadap spektrum massa pada Gambar 3 , diketahui fragmen ion $\mathrm{m} / \mathrm{z} 43,57,71$ dan seterusnya dengan penambahan 14 satuan sebagai penambahan gugus metilen $\left(\mathrm{CH}^{2+}\right)$. Ion molekul pada $\mathrm{m} / \mathrm{z} 212$ serta pola penurunan intensitas relatif pada masing-masing fragmen ion yang membentuk pola linier, menunjukkan bahwa senyawa tersebut adalah senyawa n-pentadekana (1) $\left(\mathrm{C}_{15} \mathrm{H}_{32}\right)$. Pola fragmentasi yang sama juga ditunjukkan pada spektrum massa Gambar 4. Ion molekul m/z 324 menunjukkan bahwa senyawa pada spektrum massa Gambar 4 adalah senyawa n-propakosana (2) $\left(\mathrm{C}_{23} \mathrm{H}_{48}\right)$. Analog dengan elusidasi spektrum massa Gambar 3 dan Gambar 4, hasil elusidasi pada setiap puncak fragmentogram m/z 57 fraksi polar batubara Pit Kancil, Sangatta, Kalimantan Timur teridentifikasi deret homolog n-alkana $\mathrm{C}_{13}-\mathrm{C}_{25}$. Terdapatnya homolog rantai pendek $\left(\mathrm{C}_{13}-\mathrm{C}_{29}\right)$ maupun rantai panjang $\left(\mathrm{C}_{20}-\mathrm{C}_{25}\right)$. Homolog rantai pendek dalam batubara menunjukkan bahwa kemungkinan kontribusi senyawa organik berasal dari tumbuhan tingkat rendah (alga dan sianobakteri) atau berasal dari biodegradasi nalkana rantai panjang $(\mathrm{C}>20)$. Sedangkan biomarka n-alkana rantai panjang $\left(\mathrm{C}_{20}-\mathrm{C}_{25}\right)$ memberikan informasi bahwa senyawa organik tersebut diturunkan dari lapisan lilin kutikula tanaman berkayu daratan tumbuhan tingkat tinggi. Adanya dominasi n-alkana rantai pendek pada batubara Pit Kancil, Sangatta, Kalimantan Timur, menunjukkan bahwa sebagian besar senyawa batubara Pit Kancil, Sangatta, Kalimantan Timur tersebut memiliki tingkat kematangan yang rendah (Wang dan Simoneit, 1992).

Informasi kematangan tersebut juga didukung oleh nilai kandungan proksimat batubara, yang ditunjukkan pada Tabel 1. Informasi dari analisa proksimat menunjukkan bahwa batubara Pit Kancil, Sangatta, Kalimantan Timur memiliki kandungan air dan volatile matter yang relatif tinggi, namun kandungan karbon yang rendah. Kondisi seperti ini dapat dikatakan bahwa batubara tersebut merupakan batubara muda dan digolongkan sebagai batubara jenis sub-bituminus (Singh, et al., 2010).

\section{Biomarka Naftalena}

Biomarka senyawa naftalena fraksi polar batubara Pit Kancil, Sangatta, Kalimantan Timur diidentifikasi berdasarkan fragmentogram $\mathrm{m} / \mathrm{z}$ $128+142+156+170+184+186+198$. Fragmentogram hasil analisa $\mathrm{m} / \mathrm{z} 142+156+170$ + 184 ditunjukkan pada Gambar 5, dengan MN (metilnaftalena), DMN (dimetilnaftalena), TMN (trimetilnaftalena), TeMN (tetrametilnaftalena). 


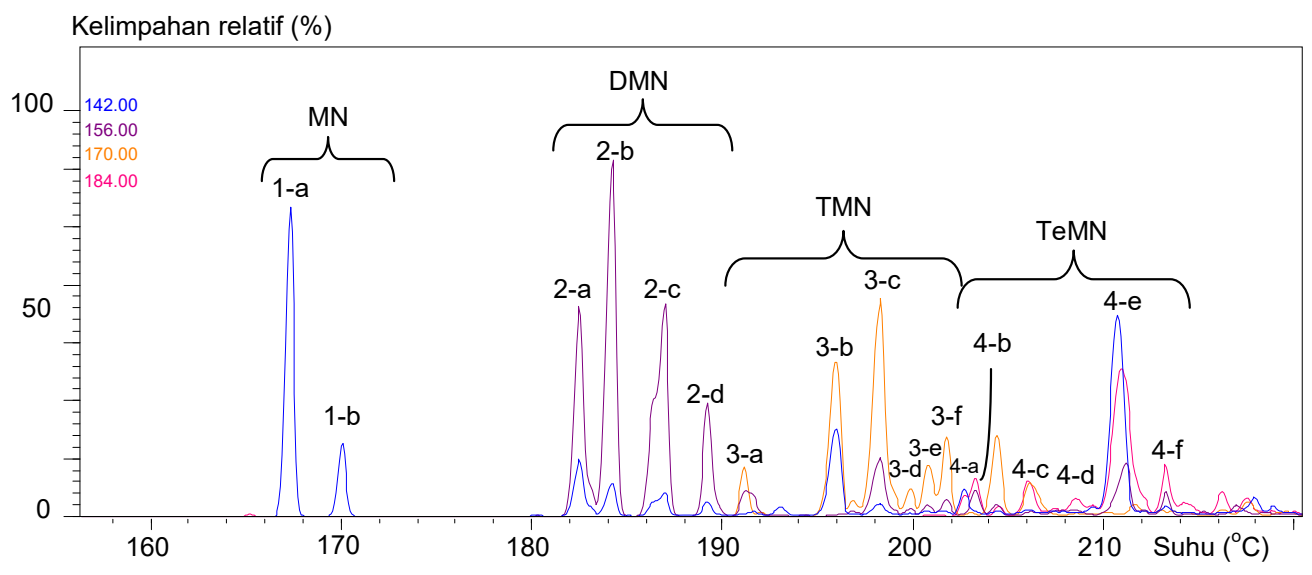

Gambar 5. Fragmentogram $\mathrm{m} / \mathrm{z} 142+156+170+184$, Program Temperatur Oven $60 \mathrm{oC}-100 \mathrm{oC}$, $10 \mathrm{oC} /$ menit, $100 \mathrm{oC}-300 \mathrm{oC}, 4 \mathrm{oC} /$ menit, Isotermal 300oC (30 menit).

Analisa puncak-1 fragmentogram Gambar 6 menghasilkan spektrum massa dengan karakteristik fragmen ion m/z 115 dan 142, yang merupakan karakteristik senyawa metil naftalena (Dutta, 2011). Spektrum massa dengan puncak ion molekul m/z 142 mengindikasikan 11 atom karbon yang dimiliki. Pelepasan fragmen ion $\mathrm{m} / \mathrm{z}$ $27\left(\mathrm{C}_{2} \mathrm{H}_{3}{ }^{+}\right)$menghasilkan fragmen ion $\mathrm{m} / \mathrm{z} 155$. Sehingga dapat disimpulkan spektrum massa tersebut merupakan spektrum massa senyawa metil naftalena (3) $\left(\mathrm{C}_{11} \mathrm{H}_{10}\right)$.

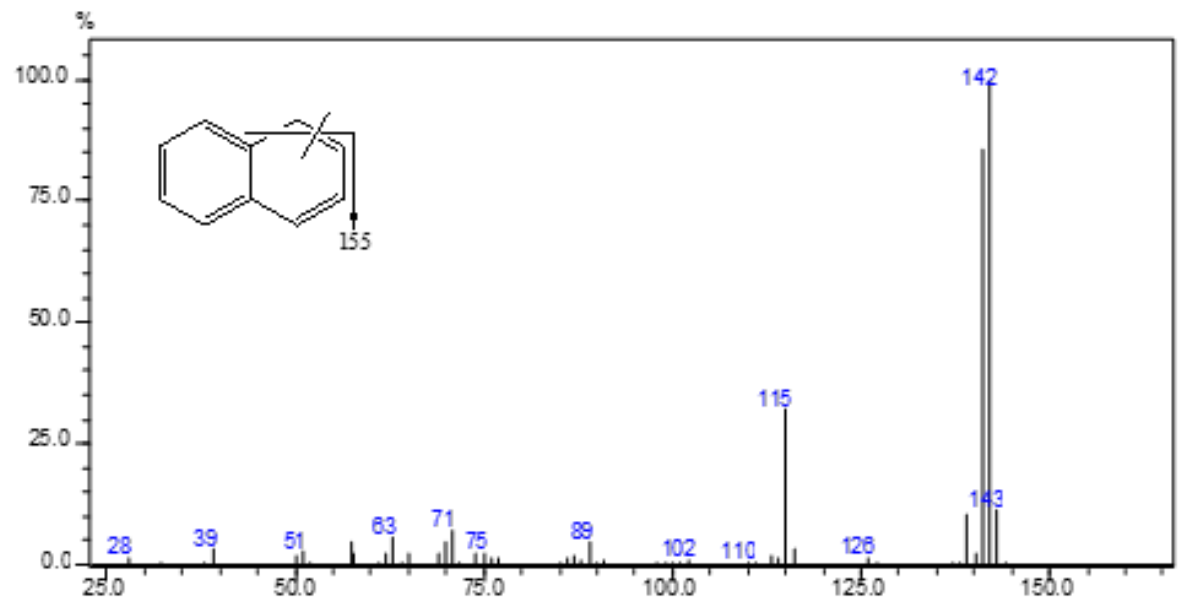

Gambar 6. Spektrum Massa Puncak 1 Fragmentogram Gambar 4.68

Analisa puncak 2 fragmentogram Gambar 5 menghasilkan spektrum massa yang ditunjukkan pada Gambar 7. Spektrum massa tersebut menunjukkan puncak dasar m/z 141 dan puncak ion molekul $\mathrm{m} / \mathrm{z}$ 156. Puncak dasar $\mathrm{m} / \mathrm{z} 141$ merupakan ciri khas senyawa n-alkil naftalena
(Williams, 1995). Puncak dasar ini diperoleh dari lepasnya fragmen ion $\mathrm{m} / \mathrm{z} 15\left(\mathrm{CH}_{3}{ }^{+}\right)$. Pelepasan $\mathrm{m} / \mathrm{z} 29\left(\mathrm{C}_{2} \mathrm{H}_{5}{ }^{+}\right)$menghasilkan fragmen ion $\mathrm{m} / \mathrm{z}$ 127. Hasil analisa menunjukkan senyawa tersebut merupakan senyawa etil naftalena $(4)\left(\mathrm{C}_{12} \mathrm{H}_{12}\right)$. 


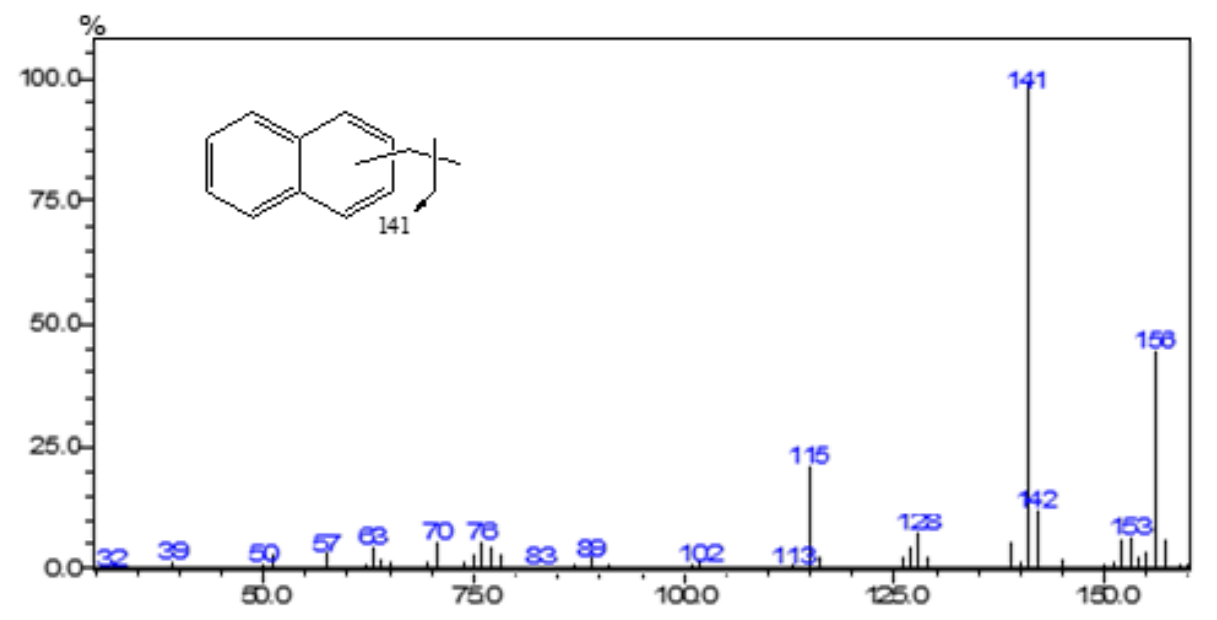

Gambar 7. Spektrum Massa Puncak 2-a Fragmentogram Gambar 4.68

Analisa puncak 2-b fragmentogram Gambar 5 menghasilkan spektrum massa Gambar 8 . Spektrum massa tersebut memiliki puncak dasar dan puncak ion molekul yang sama yaitu m/z 156 . Puncak ion molekul m/z 156 menunjukkan 12 jumlah atom karbon yang dimiliki senyawa tersebut. Fragmen ion $\mathrm{m} / \mathrm{z} 141$ diperoleh dari lepasnya fragmen ion $\mathrm{m} / \mathrm{z} \quad 15 \quad\left(\mathrm{CH}_{3}{ }^{+}\right)$. Karakteristik ion m/z 127, 141, dan 156 sebagai puncak dasar adalah ciri khas senyawa dimetil naftalena (Williams, 1995).

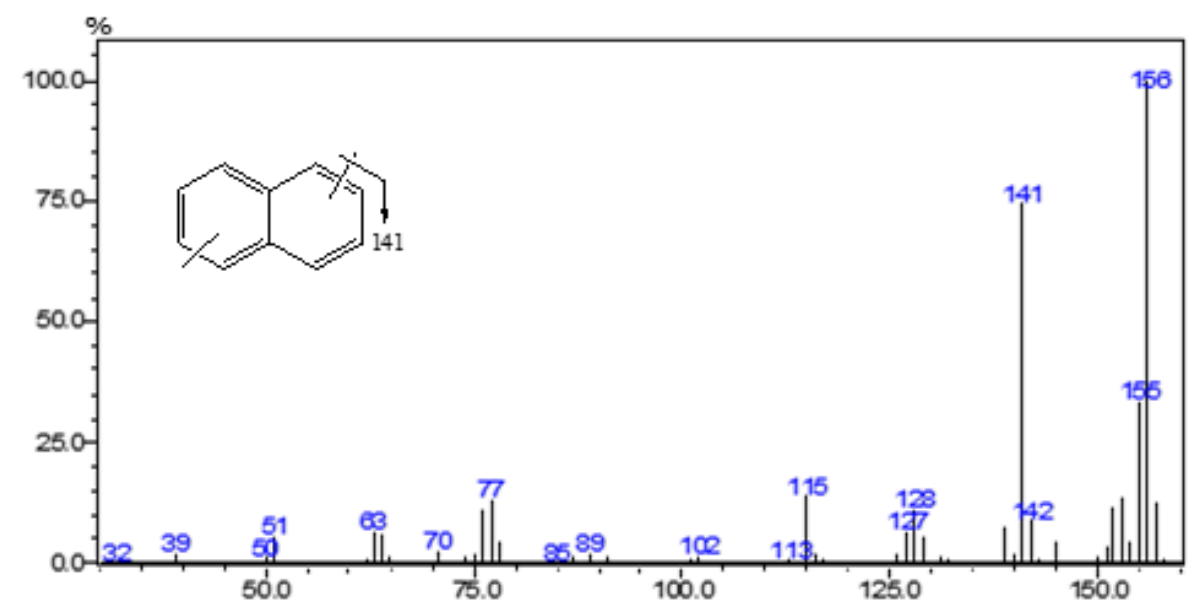

Gambar 8. Spektrum Massa Puncak 2-b Fragmentogram Gambar 4.68

Sehingga dapat disimpulkan puncak ke-4 fragmentogram Gambar 5 tersebut merupakan senyawa dimetil naftalena (5).

Demikian pula analisa puncak 5, 6, dan 7 fragmentogram Gambar 5. Ketiga puncak fragmentogram tersebut memiliki spektrum massa yang sama, yaitu puncak dasar dan puncak ion molekul m/z 156. Sehingga dapat disimpulkan ketiga puncak tersebut merupakan isomer senyawa dimetil naftalena.

Analisa puncak 3 fragmentogram Gambar 5 menghasilkan spektrum massa Gambar 9. 


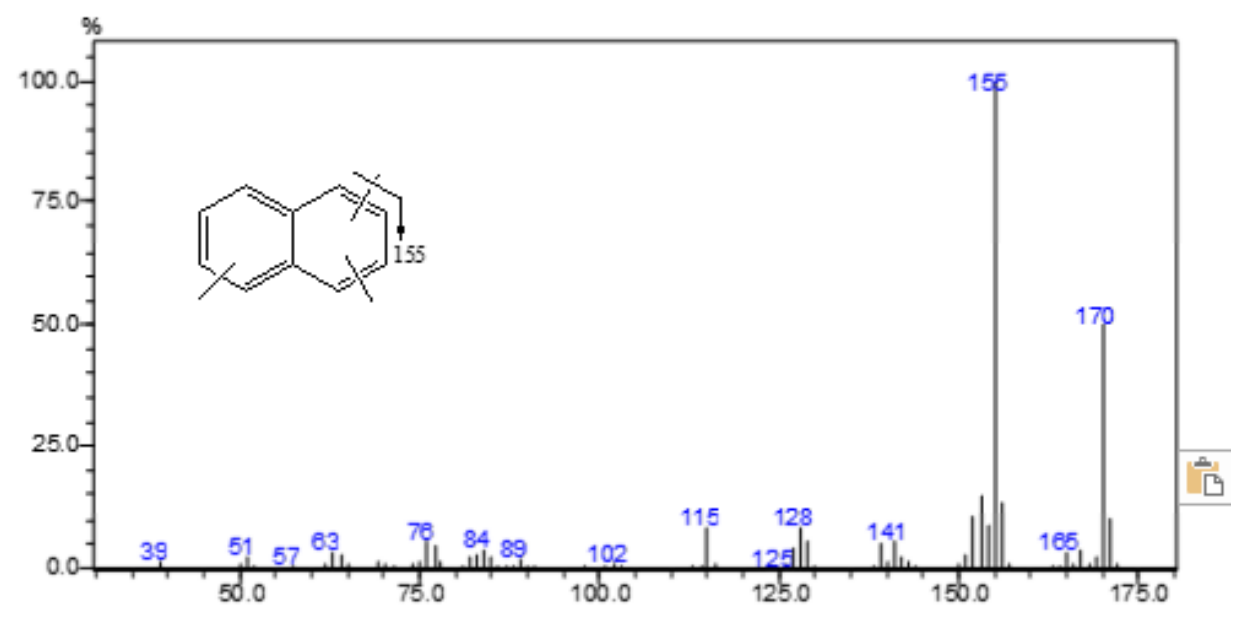

Gambar 9. Spektrum Massa Puncak 3 Fragmentogram Gambar 4.68

Spektrum massa tersebut memiliki puncak dasar $\mathrm{m} / \mathrm{z}$ 155. Fragmen ion $\mathrm{m} / \mathrm{z} 155$ diperoleh dari lepasnya fragmen ion $\mathrm{m} / \mathrm{z} \quad 15 \quad\left(\mathrm{CH}_{3}{ }^{+}\right)$. Karakteristik ion molekul m/z 170 dan m/z 155 sebagai puncak dasar merupakan ciri khas senyawa trimetil naftalena (6) (Widodo dkk.,
2009). Sehingga dapat disimpulkan puncak 3 fragmentogram tersebut merupakan senyawa trimetil naftalena. Sedangkan Analisa puncak 4 fragmentogram Gambar 5 menghasilkan spektrum massa Gambar 10.

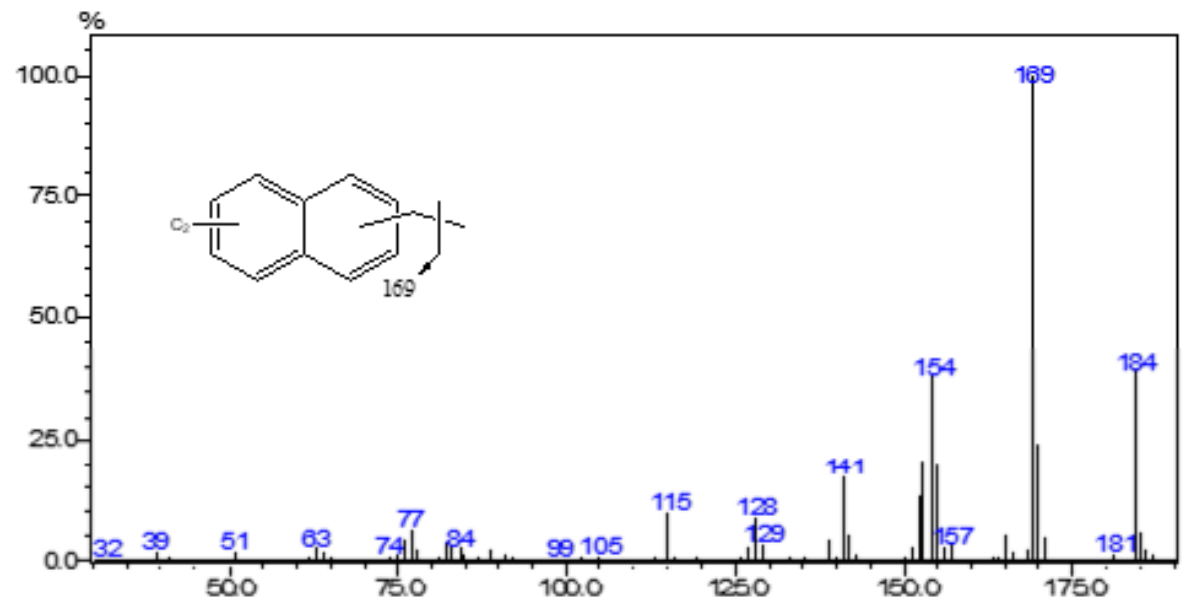

Gambar 10. Spektrum Massa Puncak 4 Fragmentogram Gambar 4.68

Spektrum massa tersebut memiliki puncak dasar $\mathrm{m} / \mathrm{z}$ 169. Fragmen ion $\mathrm{m} / \mathrm{z} 169$ diperoleh dari lepasnya fragmen ion $\mathrm{m} / \mathrm{z} \quad 15 \quad\left(\mathrm{CH}_{3}^{+}\right)$. Karakteristik ion molekul m/z 184 dan m/z 169 sebagai puncak dasar merupakan ciri khas senyawa tetrametil naftalena (Widodo dkk., 2009). Sehingga dapat disimpulkan puncak 4 fragmentogram tersebut merupakan senyawa tetrametil naftalena (7) atau norkadalena.
Distribusi isomer alkilnaftalena pada ekstrak bitumen suatu sedimen menunjukkan perubahan sedimen oleh kedalaman pemendaman dan peningkatan temperatur. Senyawa naftalena berasal dari dua sumber yang berbeda yaitu kadinana dan $\beta$-amirina. Penemuan naftalena dengan jumlah atom karbon 15 atau lebih, diduga berasal dari kadalena yang berasal dari prekursor kadinana. Alkil naftalen yang memiliki 15 atom 
karbon telah ditemukan pada banyak sedimen, batubara, dan minyak mentah dalam bentuk teraromatisasi penuh seperti kadalena (Simoneit and Mazurek, 1982; Noble et al., 1991; van Aarssen et al., 1992; Singh et al., 1994; Kalkreuth et al., 1998; Stefanova et al., 2002, 2005) dan berasal dari sesquiterpenoid dengan kadinan dan kadinol sebagai prekursor (Simoneit, dkk., 1986). Menurut Dev (1989) sumber utama sesquiterpenoid tersebut adalah compositae, Dipterocarpaceae dan Myrtaceae, yang merupakan keluarga tanaman angiospermae dan beberapa Cupressaceae yang merupakan keluarga tanaman gymnopermae. Selama periode Miocene Cekungan Kutai didominasi oleh vegetasi Dipterocarpaceae (Prasad, 1993; Appanah dan Turnbull, 1998)
Sedangkan senyawa naftalena dengan jumlah atom karbon kurang dari 15 diduga berasal dari $\beta$ amirina dari sub devisi Angiospermae, yang telah mengalami proses degradasi. Senyawa $\beta$-amirina mengalami dehidrogenasi secara bertahap dan mengalami aromatisasi pada cincin $\mathrm{A}, \mathrm{B}, \mathrm{D}$, dan E secara berturut-turut. Proses aromatisasi pada cincin D diikuti dengan proses pemutusan cincin C, sehingga pada akhir jalur penurunan didapatkan dua senyawa trimetil naftalena (Strachan, dkk., 1988). Jalur penurunan senyawa naftalena dari $\beta$-amirina ditunjukkan pada Gambar 11.

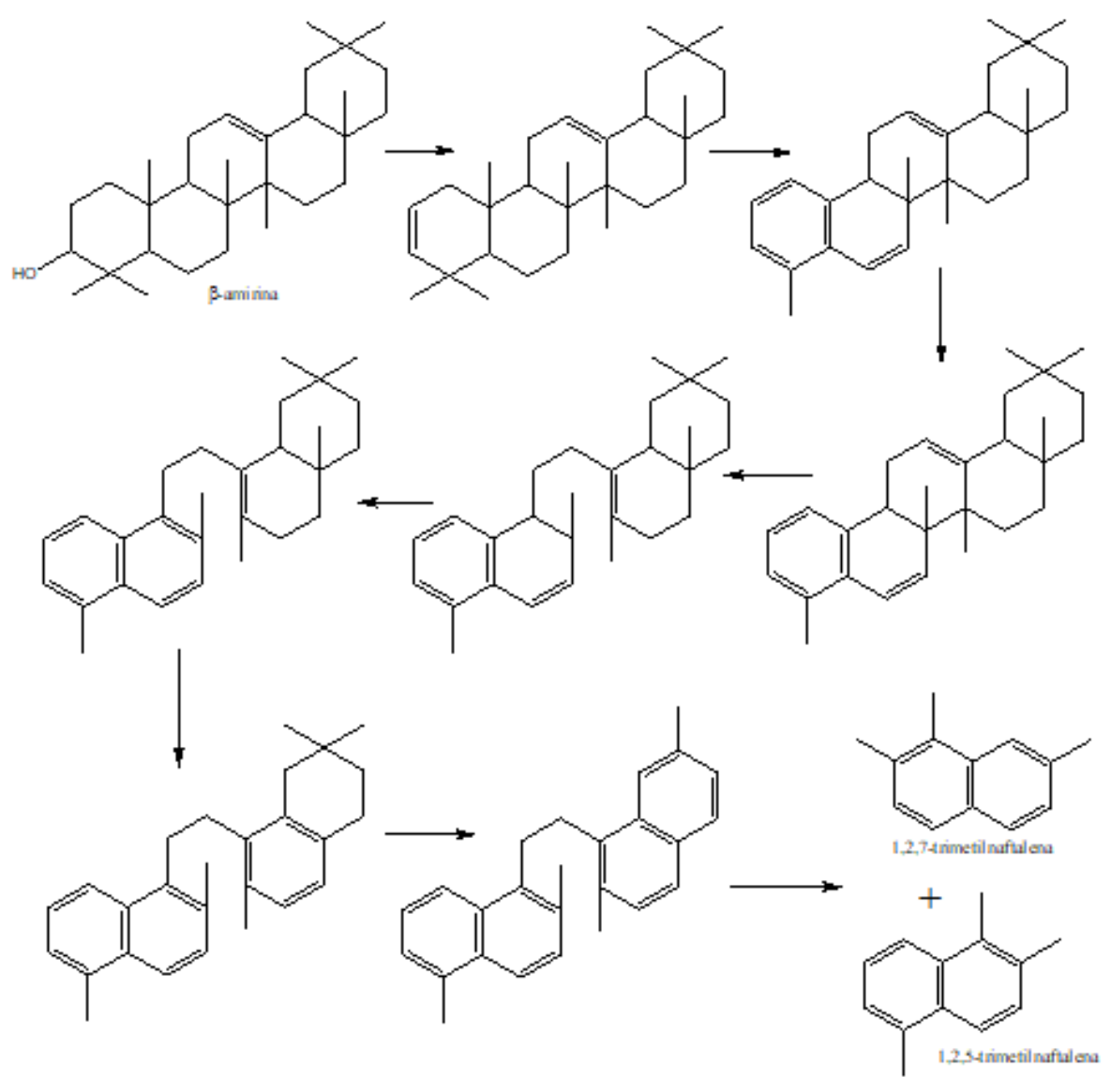

Gambar 11. Jalur Penurunan Senyawa Naftalena dari Prekursor $\beta$-amirina (Strachan, dkk., 1988). 
Biomarka Fenantrena

Biomarka fenantrena pada batubara dapat diidentifikasi berdasarkan fragmentogram $\mathrm{m} / \mathrm{z}$ $178+192+206$, yang merupakan fragmen khas senyawa hidrokarbon aromatik polisiklik dengan
3 cincin benzena (Anyakora, dkk., 2005). Hasil analisa fragmentogram m/z 178+192+206 fraksi polar batubara Pit Kancil, Sangatta, Kalimantan Timur ditampilkan pada Gambar 12.

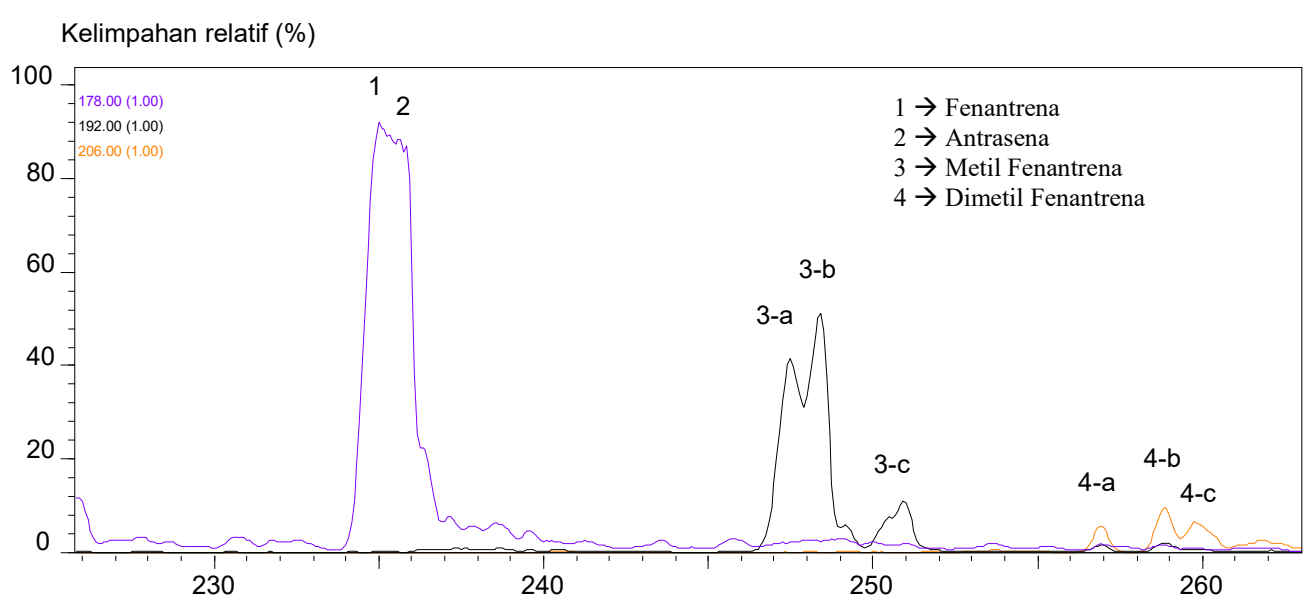

Gambar 12.Fragmentogram m/z 178+192+206 Hidrokarbon Hasil Degradasi Senyawa Makromolekul Batubara Pit Kancil, Sangatta, Kalimantan Timur, Program Temperatur Oven 50oC-290oC, $10 \mathrm{oC} /$ menit, Isotermal $290 \mathrm{oC}$ selama 20 menit.

Spektrum massa hasil analisa fragmentogram tersebut yang diantaranya ditampilkan pada Gambar 13 sampai Gambar 16.

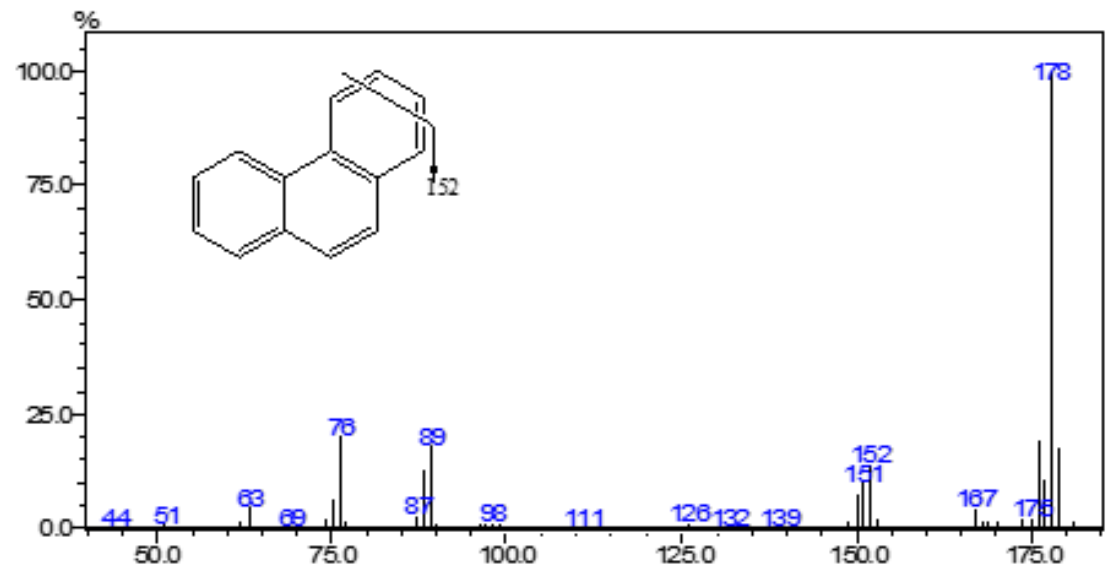

Gambar 13. Spektrum Massa Puncak 1 Fragmentogram m/z 178+192 


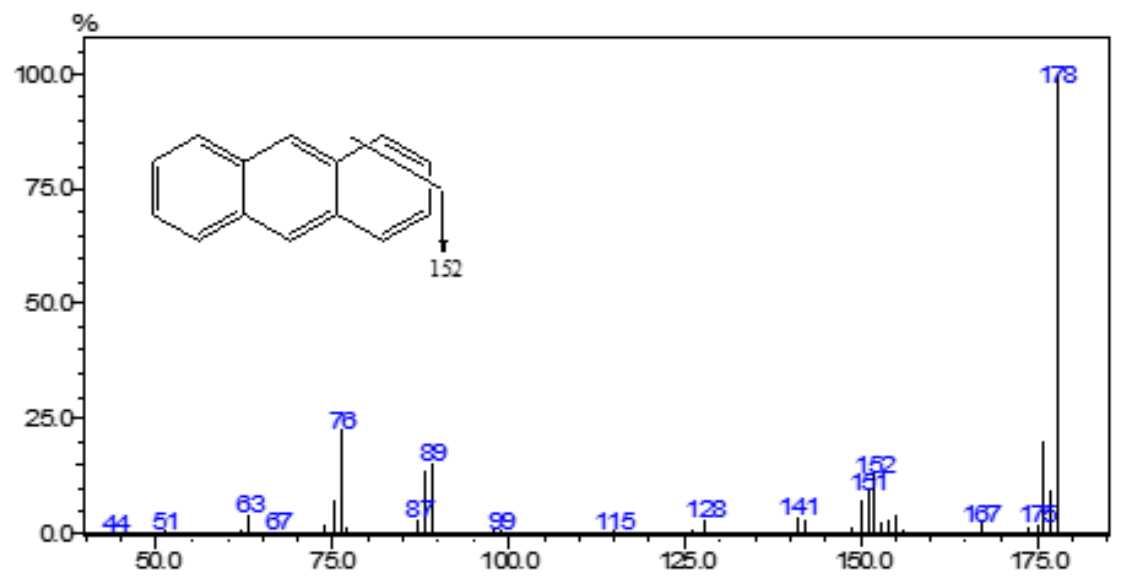

Gambar 14. Spektrum Massa Puncak 2 Fragmentogram m/z 178+192

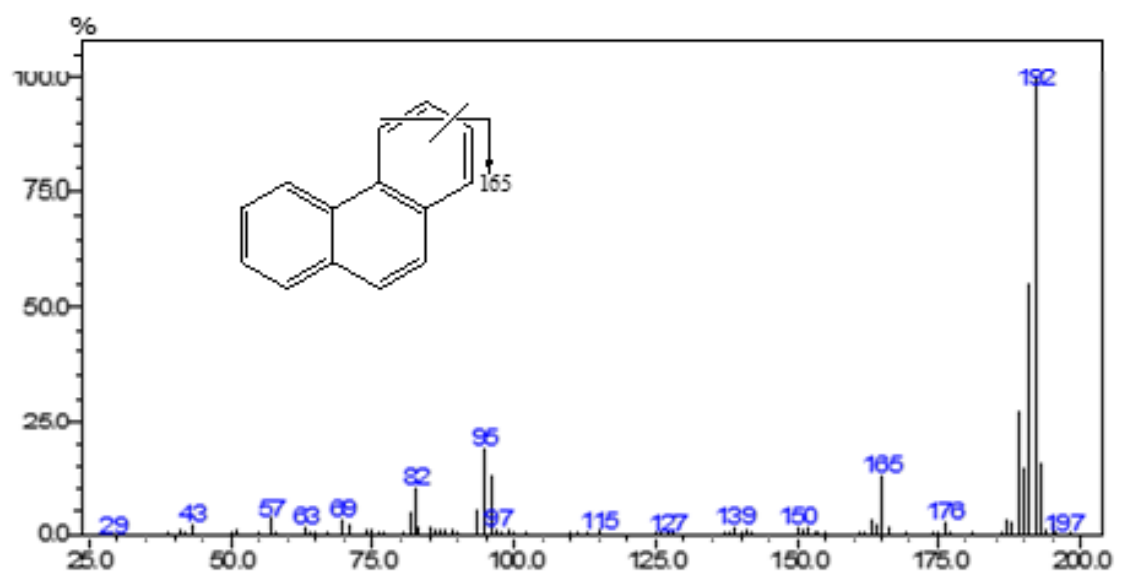

Gambar 15. Spektrum Massa Puncak 3-b Fragmentogram m/z 178+192

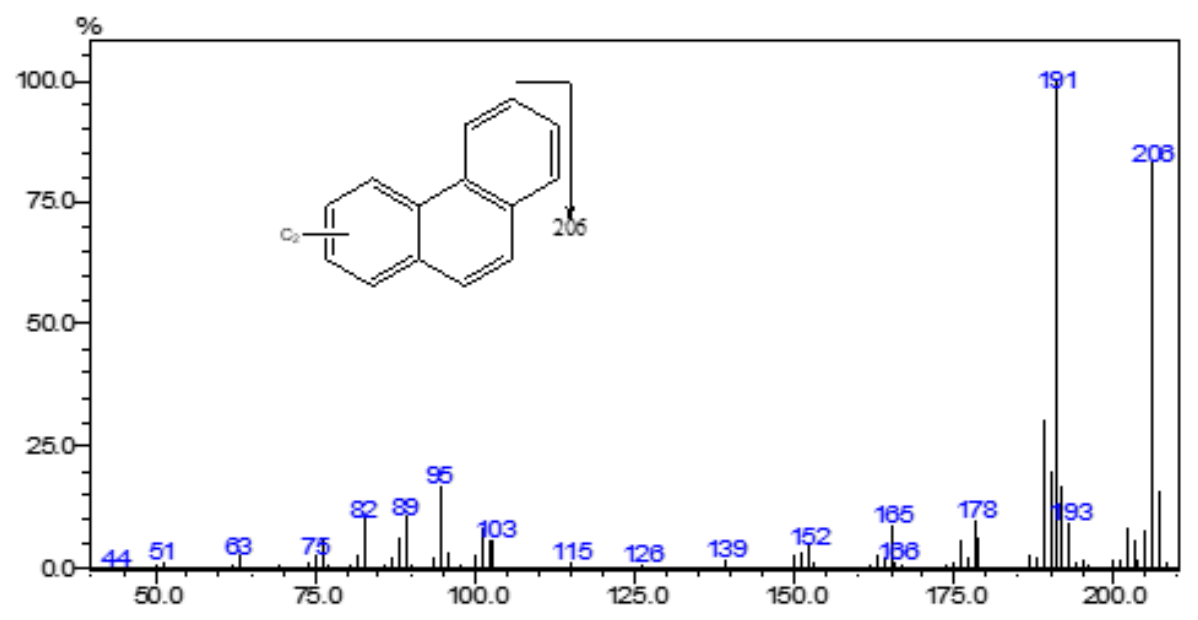

Gambar 16. Spektrum Massa Puncak 4-b Fragmentogram m/z 178+192 
Analisa spektrum massa puncak 1 pada Gambar 12, menunjukkan $\mathrm{m} / \mathrm{z} 178$ sebagai puncak dasar dan puncak ion molekulnya. Pelepasan fragmen ion $\mathrm{m} / \mathrm{z} 26(\mathrm{C} 2 \mathrm{H} 2+)$ menghasilkan fragmen ion $\mathrm{m} / \mathrm{z}$ 152. Karakteristik ion $\mathrm{m} / \mathrm{z} 152$ dan 178 merupakan ciri khas senyawa fenantrena (Anyakora, dkk., 2005). Sehingga diduga senyawa dengan spektrum massa Gambar 13 adalah senyawa fenantreana (8) $\left(\mathrm{C}_{14} \mathrm{H}_{10}\right)$. Interpretasi yang sama juga dilakukan pada spektrum massa puncak 2 (Gambar 12). Analisa spektrum massa tersebut menghasilkan fragmen ion yang serupa dengan fragmen ion yang ditunjukkan pada spektrum massa puncak 1 . Ion molekuler dan puncak dasar spektrum pada $\mathrm{m} / \mathrm{z}$ 178 menunjukkan bahwa senyawa tersebut merupakan senyawa antrasena (9)

Analisa puncak 3-b pada fragmentogram Gambar 12, menghasilkan spektrum massa Gambar 15, dengan m/z 192 sebagai puncak dasar dan puncak ion molekulnya. Pelepasan fragmen ion $\mathrm{m} / \mathrm{z} 15$ $\left(\mathrm{CH}_{3}{ }^{+}\right)$menghasilkan fragmen ion $\mathrm{m} / \mathrm{z} 177$. Pemutusan fragmen ion $\mathrm{m} / \mathrm{z} \quad 27 \quad\left(\mathrm{C}_{2} \mathrm{H}_{3}{ }^{+}\right)$ menghasilkan fragmen ion $\mathrm{m} / \mathrm{z}$ 165. Analisa spektrum massa dengan fragmen ion $\mathrm{m} / \mathrm{z} 152,177$ dan 192 menunjukkan karakteristik senyawa metil fenantrena (10) (Anyakora, dkk., 2005).

Analisa kelompok spektra puncak 4-b fragmentogram Gambar 12, menghasilkan spektrum massa seperti yang ditunjukkan pada Gambar 16. Pada spektrum massa tersebut diketahui puncak dasar spektrum pada $\mathrm{m} / \mathrm{z} 191$, yang terbentuk dari lepasnya fragmen ion $\mathrm{m} / \mathrm{z} 15$ $\left(\mathrm{CH}_{3}{ }^{+}\right)$. Identifikasi ion molekul pada $\mathrm{m} / \mathrm{z} 202$ menunjukkan bahwa senyawa tersebut adalah senyawa dimetil fenantrena (11).

Prekursor senyawa fenantrena ditemukan pada tumbuhan tingkat tinggi pada jenis tanaman Gimnospermae (Simoneit, dkk., 1986). Pemutusan gugus metil dan proses katagenesis yang terjadi pada steran akan memungkinkan terjadinya pemutusan cincin $\mathrm{D}$ dan mengalami aromatisasi lebih lanjut membentuk senyawa fenantrena (Mango, 1989), sebagaimana ditunjukkan pada gambar 17.

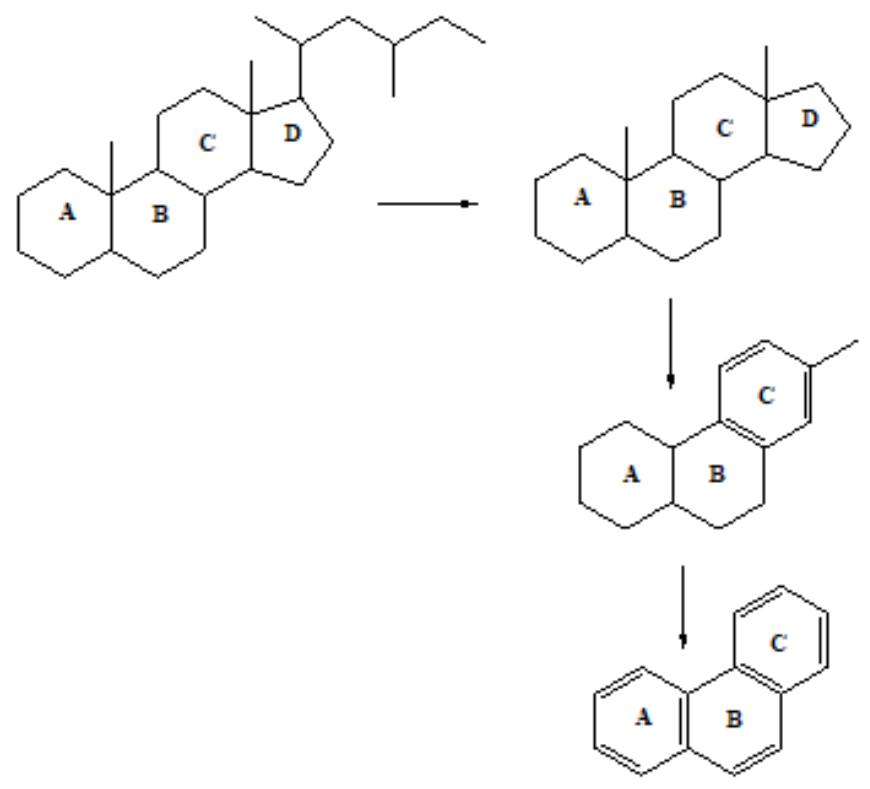

Gambar 17 Pembentukan Senyawa Fenantrena dari Steran

Senyawa turunan fenantrena yang diturunkan dari tanaman Gimnospermae juga ditemukan pada batubara zaman Miosen di Sumatra dan Kalimantan Timur (Anggayana, dkk., 1996). 
Ditemukannya biomarka turunan fenantrena pada batubara Pit Kancil, Sangatta, Kalimantan Timur menunjukkan masukan organik batubara berasal dari tumbuhan tingkat tinggi sub-devisi Gimnospermae pada zaman Miosen dan telah melewati proses diagenesis.

\section{Korelasi Biomarka Batubara dengan Biomarka Produk Pencairannya}

Senyawa hidrokarbon hasil degradasi fraksi polar batubara pit Kancil, Sangatta, Kalimantan Timur dianalisa dengan KG-SM dan diperoleh penelusuran terhadap kromatogram total tersebut beberapa tipe biomarka antara lain n-alkana $\mathrm{C}_{13}-$ $\mathrm{C}_{25}$, alkil naftalena dan biomarka alkil fenantrena. Biomarka tersebut juga ditemukan pada komposisi senyawa hidrokarbon hasil pencairan batubara Kalimantan Timur, dimana Hasil analisa fraksi minyak light oil n-alkana $\mathrm{C}_{11-\mathrm{C}_{23}}$ menunjukkan bahwa fraksi minyak tersebut berpotensi sebagai bahan bakar solar. (Ulfaniyah dan Burhan, 2012). Sedangkan komposisi senyawa hidrokarbon pada fraksi minyak naphtha dengan rentang n-alkana $\mathrm{C}_{9}-\mathrm{C}_{16}$, yang terkandung pada fraksi minyak naphtha menunjukkan bahwa fraksi minyak tersebut berpotensi sebagai bahan bakar kerosin (Ulfaniyah dan Burhan, 2012).

Senyawa naftalen dan turunannya banyak ditemukan dalam minyak mentah di cekungan Indonesia seperti Crude oil pada Cekungan Arjuna, Jawa Barat yang mengandung senyawa light hydrocarbon kompleks (C>10). Pada minyak tersebut didominasi oleh kandungan senyawa dimetil naftalen dan hidrokarbon alkana rantai panjang (Horsfield, dkk., 1988). Senyawa turunan alkilnaftalen, terutama metilnaftalen merupakan salah satu komponen utama bahan bakar solar (Tancell, dkk., 1996) yang berguna untuk meningkatkan angka cetan solar (Dechamps, 2010).

\section{SIMPULAN}

Senyawa hidrokarbon hasil degradasi fraksi polar batubara pit Kancil, Sangatta, Kalimantan Timur dianalisa dengan KG-SM dan diperoleh penelusuran terhadap kromatogram total beberapa tipe biomarka antara lain n-alkana $\mathrm{C}_{11}-\mathrm{C}_{23}$, alkil naftalena dan biomarka alkil fenantrena. Teridentifikasinya senyawa n-alkana $\mathrm{C}_{11}-\mathrm{C}_{23}$ menunjukkan bahwa masukan bahan organik pembentuk batubara berasal dari tanaman tingkat tinggi. Adanya dominasi n-alkana rantai pendek menunjukkan bahwa sebagian besar senyawa batubara tersebut memiliki tingkat kematangan yang rendah. Adanya alkil naftalena dan alikil fenantrena menunjukkan menunjukkan bahwa masukan organik batubara berasal dari tumbuhan tingkat tinggi sub-devisi Gimnospermae pada zaman Miosen dan telah melewati proses diagenesis. Hasil analisa biomarka fraksi polar batubara Pit Kancil, Sangatta, Kalimantan Timur menunjukkan tingkat kematangan batubara yang rendah. Hal ini didukung oleh hasil analisa proksimat batubara yang menunjukkan kadar air dan vollatile matter yang cukup tinggi dan kadar karbon yang relatif rendah.

Berdasarkan analisa biomarka, dan korelasi terhadap produk pencairan batubara, maka batubara Pit Kancil, Sangatta, Kalimantan Timur berpotensi untuk dicairkan pada proses pemanfaatannya.

\section{Reference}

Anggayana, K., (1996). Mikroskopische und organischgeochemsiche Untersuchungen an Kohlen aus Indonesien ein Beitrag zur Genese und Fazies verschiedener Kohlenbecken. Dissertation. RWTH Aachen, Germany. p. 224.

Anyakora, C., dkk., 2005. GC/MS Analysis of Polynuclear Aromatic Hydrocarbons in Sediment Samples from The Niger Delta Region, Chemosphere, 60, 990-997.

Dev, S., 1989. Terpenoids. In: Rowe, J.W. (Ed.), Natural Products of Woody Plants I. Springer-Verlag, Berlin, pp. 691807.

Dutta, S., Mathews, P.R., Singh, B.D., Tripathi, S.M., Singh, A., Saraswati, P.K., Banerjee, S., Mann, U., (2011). Petrology, palynology and organic geochemistry of Eocene lignite of Matanomadh, Kutch Basin, western India: implications to depositional environment and hydrocarbon source potential. International Journal of Coal Geology 85, 91-102.

Girriana, M., 2012, Percepatan Pembangunan Industri Gas Bumi, Badan Perencanaan Pembangunan Nasional, Laporan Akhir Kajian.

Hazai, I., Alexander, G., Essiger, B. \& Szekely, T. (1988). Identification of aliphatic biological markers in brown coal. Fuel, 67, 897-904. 
Horsfield, B., Yordy, K.L., dan Crelling, J.C., 1988. Determining the Petroleum Generating Potential of Coal Using Organic Geochemistry and Organic Petrology, Organic Geochemistry, 13, 121-129.

Kalkreuth, W., Keuser, C., Fowler, M., Li, M., McIntyre, D., Püttmann, W., Richardson, R., 1998. The petrology, organic geochemistry and palynology of Tertiary age Eureka Sound Group coals, Artic Canada. Organic Geochemistry 29, 799-809.

Karlsson,O. The Composition of Peat Liquids : 2. Functional Group Analysis of Peat Liquefaction Products. Fuel. 1990; 69:613-16.

Legarreta, J.A., Arias, P.L., de Marco, I. Chemical and Petrograpic Characterization and Liquefaction Yield of Spanish Coals. Fuel Processing Technology. 1987 15:293-305.

Noble, R. A., Wu, C. H., Atkinson, C. D., (1991). Petroleum generation and migration from Talang Akar coals and shales offshore N.W. Java, Indonesia. Organic Geochemistry, 17, 363-374.

Nugroho Hanan. Tinjauan terhadap Infrastruktur Transportasi Batubara Kalimantan. Jakarta: BAPPENAS, Edisi 03/th XI; 2006.

Peters, K. E \& Moldowan, S. M. (1993). The biomarkers guide interprenting molecular fossil in petroleum and ancient sediment. Prentice Hall, Inc., New Jersey

Petrov, A., Vorobieva, N. S. \& Zemskova, Z. K. (1985). Sterenes and triterpenes in brown coals, Org. Geochem., 8(4), 269273

Prasad, M., 1993. Siwalik (Middle Miocene) woods from the Kalagarh area in the Himalayan foot hills and their bearing on palaeoclimate and phytogeography. Review of Paleobotany and Palynology 76, 49-82.

Simoneit, B.R.T., Mazurek, M.A., 1982. Organic matter of the troposphere-II. Natural background of biogenic lipid matter in aerosols over the rural Western United States. Atmos. Environ. 16, 2139-2159.

Simoneit, R.B.T (1986), "Diterpenoid compound and other lipid in deep-see sediment and their geochemical significance", Geochimica at Chosmochimica Acta, 41, 463-476.

Singh, R. K., Alexander, R., dan Kagi, R. I., (1994), Identification and Occurence of Norcadalenes and Related Compounds In Crude Oils Sediments, Organic Geochemistry, 21, No.3/4, 249-256

Starchan, Michael, G., Alexander, R., dan Kagi, R.I., (1988), “A Comparison of selected biological marker compunds in some natural and synthetic liquid fuel". GPO Box U1987, Perth 6001, Western Australia.

Stefanova, M., Markovab, K., Marinova, S., Simoneit, B. R. T., (2005), "Molecular indicators for coal-forming vegetation of the Miocene Chukurovo lignite Bulgaria", Fuel, 84, $1830-1838$.

Stefanova, M., Oros, D.R., Otto, A., Simoneit, B.R.T., 2002. Polar aromatic biomarkers in the Miocene Maritza-East lignite, Bulgaria. Organic Geochemistry 33, 1079-1091.
Sukandarrumidi. (1995). Batubara dan Gambut. Gadjah Mada University Press, Yogyakarta.

Sukandarrumidi. (1995). Batubara dan Gambut. Gadjah Mada University Press, Yogyakarta.

Tancell, P.J., Rhead, M.M., Pemberton, R.D., dan Braven, J., 1996. Diessel Combution of an Alkylated Polycyclic Aromatic Hydrocarbon, Fuel, 75, 717-723

Tuo, J., Wang, X., Chen, J., \& Simoneit, B. R. T. (2003). Aliphatic And Diterpenoid Hydrocarbons And Their Individual Carbon Isotope Composition In Coals From Liaohe Basin, China. Organic Geochemistry, 34, 1615-1625.

van Aarssen, B. G. K., Hessels, J. K. C., Abbink, O. A., de Leeuw, J. W., (1992), "The occurrence of polycyclic sesqui-, triand oligoterpenoid, derived from a resinsous polymeric cadinen in crude oil from Southeast Asia”, Geochemica et cosmochimica Acta, 56, hal. 1231-1246

Wang, T. G. dan Simoneit, B. R. T., (1990), "Organic geochemistry and coal petrology of tertiary brown coal in the Zhoujing mine, Baise basin, South China. II. Biomarker assemblage and significance, Fuel, 69, hal. 12-20

Widodo, S., Bechtel, A., Anggayana, K., dan Püttmann, W. (2009), Reconstruction of Floral Changes During Deposition of the Miocene Embalut Coal from Kutai Basin, Mahakam Delta, East Kalimantan, Indonesia by use of Aromatic Hydrocarbon Composition and Stable Carbon Isotope Ratios of Organic Matter, Organic Geochemistry, 40, 206218. 